\title{
Naturally occurring arsenic in sandstone aquifer water supply wells of northeastern Wisconsin. [DNR-110] 1995
}

Burkel, Rebecca S.; Stoll, Richard C. Madison, Wisconsin: Wisconsin Department of Natural Resources, 1995

https://digital.library.wisc.edu/1711.dl/5NOTIA6OTDCEH8J

http://rightsstatements.org/vocab/InC/1.0/

For information on re-use see:

http://digital.library.wisc.edu/1711.dl/Copyright

The libraries provide public access to a wide range of material, including online exhibits, digitized collections, archival finding aids, our catalog, online articles, and a growing range of materials in many media.

When possible, we provide rights information in catalog records, finding aids, and other metadata that accompanies collections or items. However, it is always the user's obligation to evaluate copyright and rights issues in light of their own use. 
selmuth - WR/a

\# 110

NATURALLY OCCURRING ARSENIC IN SANDSTONE AQUIFER WATER SUPPLY

WELLS OF NORTHEASTERN WISCONSIN

July 14, 1995

Rebecca S. Burkel and Richard C. Stoll, P.G.

Wisconsin Department of Natural Resources 


\title{
ABSTRACT \\ NATURALLY OCCURRING ARSENIC IN SANDSTONE AQUIFER WATER SUPPLY WELLS OF NORTHEASTERN WISCONSIN
}

\author{
Rebecca S. Burkel and Richard C. Stoll, P.G. \\ Wisconsin Department of Natural Resources
}

July 14,1995

Concentrations of arsenic, ranging from 1.0 to 12000 micrograms per liter $(\mu \mathrm{g} / \mathrm{L})$, were detected in groundwater over a broad geographic region in Outagamie and Winnebago Counties in Wisconsin. The hydrologic and geochemical properties of the area were examined and the source of arsenic determined to be natural. Groundwater collected from two geologic formations, the St. Peter Sandstone and the overlying Platteville/Galena Dolomite, were found to be the principle sources of the elevated arsenic concentrations. These two formations supply most of the drinking water to a large portion of eastern Wisconsin.

Arsenic levels of $5 \mu \mathrm{g} / \mathrm{L}$ or greater were found in 622 of 1943 water supply wells sampled in Outagamie and Winnebago Counties. When arsenic was detected at or above 5 $\mu \mathrm{g} / \mathrm{L}$, the concentrations generally ranged between $5 \mu \mathrm{g} / \mathrm{L}$ and $16 \mu \mathrm{g} / \mathrm{L}$. These levels are below the NR 140 Wisconsin Administrative Code enforcement standard (ES) of $50 \mu \mathrm{g} / \mathrm{L}$ for groundwater but above or equal to the $5 \mu \mathrm{g} / \mathrm{L}$ preventative action limit (PAL). The enforcement standard of $50 \mu \mathrm{g} / \mathrm{L}$ for arsenic was exceeded in 68 of 1943 water supply wells sampled in Outagamie and Winnebago Counties. Arsenic was also detected in water supply wells at concentrations below $5 \mu \mathrm{g} / \mathrm{L}$.

Laboratory chemical analysis of sandstone and dolomite drill cuttings obtained during construction of water supply wells in the area also revealed natural arsenic concentrations ranging from 1.7 to 67 milligrams per kilogram $(\mathrm{mg} / \mathrm{kg})$. Water wells containing elevated levels of arsenic varied in depth and are often open to different depths generally within the Platteville/Galena Formation. However, some of the wells with elevated concentrations of arsenic have casings which terminate in the St. Peter Sandstone and the overlying Platteville/Galena Formation is not present. Results suggest that when present, the geologic contact between the St. Peter Sandstone and the overlying Platteville/Galena Formation is the predominant source of elevated arsenic concentrations within groundwater in the study area.

Three wells were found within Outagamie County to have an unusually low $\mathrm{pH}$.

Preliminary results suggest that the cause of the low $\mathrm{pH}$ in each of these wells is of natural origin induced by the oxidation of pyrite, marcasite or iron sulfide minerals commonly associated with acid mine drainage. In this reaction pyrite or marcasite are oxidized forming sulfuric acid. The presence of acidic water may cause metals to leach from native rock formations into the water supply.

Following this, the study was expanded to four other neighboring counties (Brown, Shawano, Oconto and Marinette) which follow the same geologic trend. The expanded study indicates that native arsenic in water wells exists at concentrations below the $50 \mu \mathrm{g} / \mathrm{l}$ drinking water standard in three (Shawano, Oconto, Marinette) of the four counties. However, arsenic exceeded the drinking water standard in 18 of 76 water supply wells in Brown County.

Based on the data gathered from this study an arsenic advisory area for both Outagamie and Winnebago Counties was designated. Guidelines were developed for well drillers and owners constructing new wells within the advisory area to reduce the likelihood of arsenic presence in the water supply. Fifteen wells containing arsenic concentrations exceeding the health advisory were successfully reconstructed or new wells were constructed based on the guidelines developed. These constructions, eliminated or substantially reduced arsenic levels in the well water supplies. 


\section{INTRODUCTION}

Arsenic contamination in water supplies was first identified in two different locations in Winnebago County, Wisconsin, in 1987. Following this the Wisconsin Department of Natural Resources (WDNR) initiated a study in 1991 to investigate the occurrence of arsenic in private wells in Outagamie and Winnebago Counties. The objective of this study was to determine the lateral and vertical distribution of naturally occurring arsenic in groundwater and geologic formations. The study results were used to develop special well casing and well construction criteria for new wells in affected areas.

Arsenic presents a potential health concern for individuals supplied by water with elevated arsenic concentrations. Arsenic is considered to be a carcinogen, teratogen and mutagen. Long-term effects of exposure to low levels of arsenic can increase the risk for skin cancer, and may cause hyperpigmentation, heart failure, blackfoot disease, digestive and nervous system problems (Eisler, 1988, Marquis, 1989). Routine water sampling or sampling just after well construction is generally only for bacteria and does not normally include analysis for arsenic in Wisconsin.

Arsenic a naturally occurring element in the Earth's crust is found in all living things. It ranks 20 th in abundance in the Earth's crust and 12th in the human body. Naturally occurring arsenic is found primarily in sedimentary and igneous rocks (Irgolic, 1982). Arsenic enters the environment through natural processes or via human activity. Natural processes that influence the presence of arsenic are volcanic emissions and weathering of arsenic-containing rocks, arsenopyrite (FeAsS) and realgar (AsS). Arsenic tends to exist naturally with sulfide ores of iron, nickel, and cobalt (Eisler, 1988). Presently, anthropogenic sources are thought to contribute three times more arsenic than natural sources (Eisler, 1988) which include fossil fuel combustion, pesticide use, copper and lead smelting, and improper disposal of arsenic compounds.

At the present time the drinking water standard for total arsenic is $50 \mu \mathrm{g} / \mathrm{L}$. This was established by the Safe Drinking Water Act (SDWA) in 1986.

\section{Geology of Outagamie and Winnebago Counties, the Study Area}

The crystalline rocks of the Precambrian age underlie all of Outagamie and Winnebago Counties. The Precambrian crystalline rocks are composed primarily of granite and except for fractures are generally impermeable.

The Cambrian sequence rests on the irregular and highly eroded surface of the Precambrian rock (Olcott, 1966). The Cambrian System comprises three formations, the Trempealeau, Franconia, and Dresbach. The Cambrian System is made of fine to coarse grained sandstone. These sandstones are a major source of groundwater especially for municipal wells. The surface of the Cambrian System is fairly regular and smooth (Olcott, 1966).

The Ordovician System contains the Prairie du Chien Group, the St. Peter Sandstone, and the Platteville/Galena Formation. The Prairie du Chien is a relatively unproductive water yielding unit. The Prairie du Chien Group consists of dolomite with thin layers of white sandstone and green shale (Olcott, 1966). The upper surface of the Prairie du Chien is highly irregular (Olcott, 1966). A limited amount of water is found in fractures, joints, and bedding planes (Olcott, 1966). The Prairie du Chien has a lower permeability than that of the underlying Cambrian sandstones and it may hinder the vertical migration of groundwater (Olcott, 1966).

The St. Peter Sandstone is a productive water-yielding unit. It consists of fine-to coarsegrained dolomitic sandstone (LeRoux, 1957). The St. Peter Sandstone rests on the Prairie du Chien Group filling in low areas but it is absent on the Prairie du Chien highs (Olcott, 1966). Water yields from the St. Peter Sandstone are limited by the presence of shale and by the limited thickness of the formation. Thicknesses range from 0 to $30.5 \mathrm{~m}$ (0 to $100 \mathrm{ft}$ ) in the study area (Thwaites, 1961). 
The overlying Platteville/Galena Formations are composed of sandy-gray to bluish-gray dolomite with fine to medium grained sandstone near the base (Olcott, 1966). The formations are generally located in the eastern part of both counties and generally yields little water to wells (LeRoux, 1956). However, sufficient quantity of water exists in certain locations to furnish private well supplies. The water that is present is found in joints, bedding planes and fractures within the rocks. The Platteville/Galena has a lower permeability than the St. Peter Sandstone below and therefore may cause artesian conditions within the underlying unit (Olcott, 1966). The groundwater flows in a southeasterly direction across both counties (Olcott, 1966, LeRoux, 1956). A map of the bedrock geology and primary study wells for both counties is found in Figure 1.

\section{METHODOLOGY}

\section{Well Water Sample Collection and Analysis}

Initial study samples were collected by the WDNR. These were later supplemented by a private well owner sampling program. The WDNR sample collection followed guidelines set up in the WDNR Groundwater Sampling Procedures Field Manual and the WDNR Groundwater Sampling Procedures Guidelines both developed by Lindorf, Feld, and Connelly (1987). All samples were collected from a cold water tap situated prior to any inline treatment device (e.g. a water softener or filter). Samples were collected after flushing the water supply tap for three to five minutes or a couple of minutes after the pump started running. This procedure was used to ensure the water sample represented in situ groundwater and not water standing in the pipes. All samples were collected, preserved with $2.5 \mathrm{ml} / 35 \% \mathrm{HNO}_{3}$, and labeled in appropriate sample containers supplied by the Wisconsin State Laboratory of Hygiene (WSLH). Samples were analyzed by high temperature graphite furnace atomic absorption methods.

For those samples collected as part of the private well owner sampling program the private well owners collected and labeled water samples, in sample containers provided by a State Certified Laboratory. The private well owner returned them to the County Department of Health which in turn had them analyzed for arsenic by a State Certified Laboratory. Each sample was analyzed by high temperature graphite furnace atomic absorption methods. The methods had either a $2 \mu \mathrm{g} / \mathrm{L}$ or a $3 \mu \mathrm{g} / \mathrm{L}$ lower detection limit. All homeowners who participated in the arsenic sampling were advised of their As result by their respective County Health Department.

All well locations were plotted on 7.5 minute USGS topographic maps or keyed with a global position system (GPS) for digitizing into a geographic information system (GIS). Multiple information layers including land net, railroads, trunk highway network, local roads, hydrology, bedrock geology, glacial geology, potentiometric surface and all known point and non-point potential groundwater contamination sources were created for all of Northeast Wisconsin. This information was analyzed with respect to arsenic contamination utilizing PC ARC/Info and ARC View GIS software located in the office. Various map products were also produced as part of this project. Based on the collected data a map of the affected area was created indicating an arsenic advisory area for Outagamie and Winnebago Counties. (Figure 2).

\section{Geophysical Well Investigation Methods}

\section{Inflatable Packer Tests}

Packer tests were used to isolate and sample specific subsurface water-bearing zones within wells and thus determined potential areas in the subsurface causing poor water quality. The two wells chosen for packer testing are referred to as well 5 and well 1 . Both these wells were selected based on their depths and the identified arsenic concentration of the 


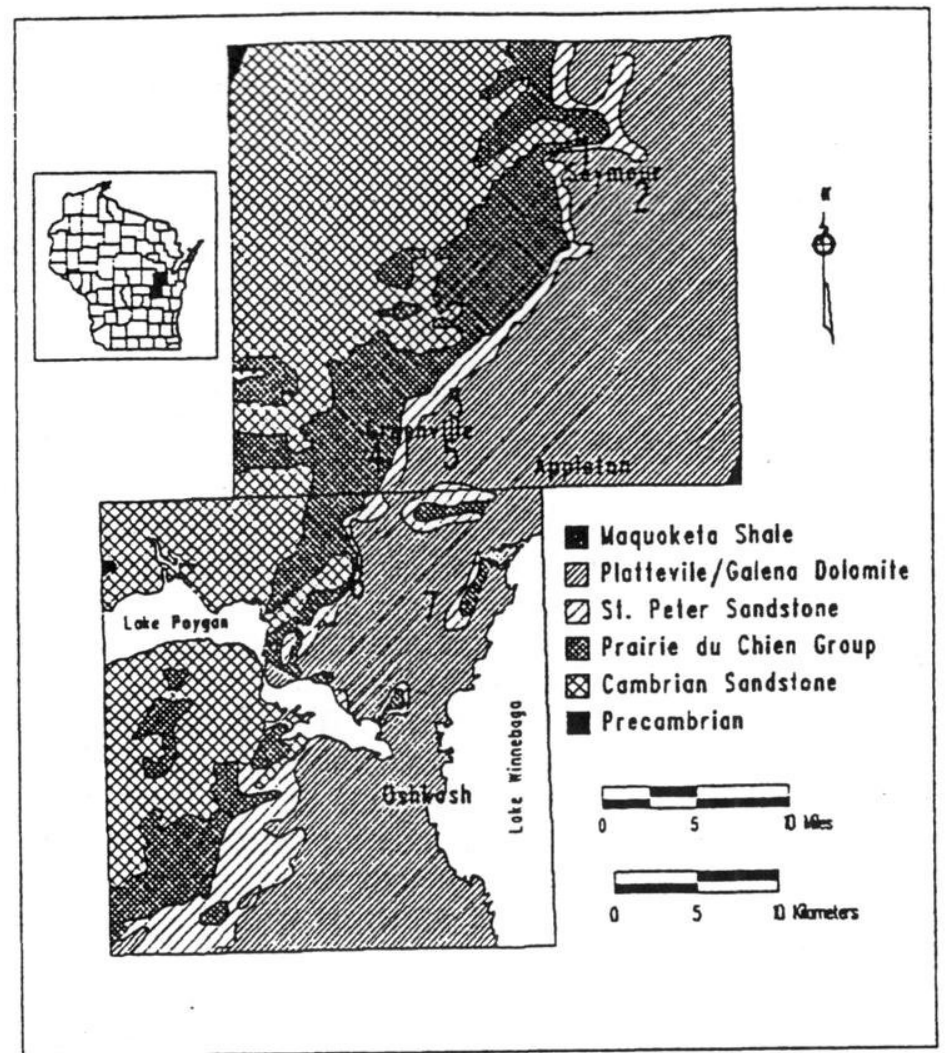

Fig. 1. Bedrock geologic mop of Outagamie and Winnebogo Counties depicting seven well locations examined.

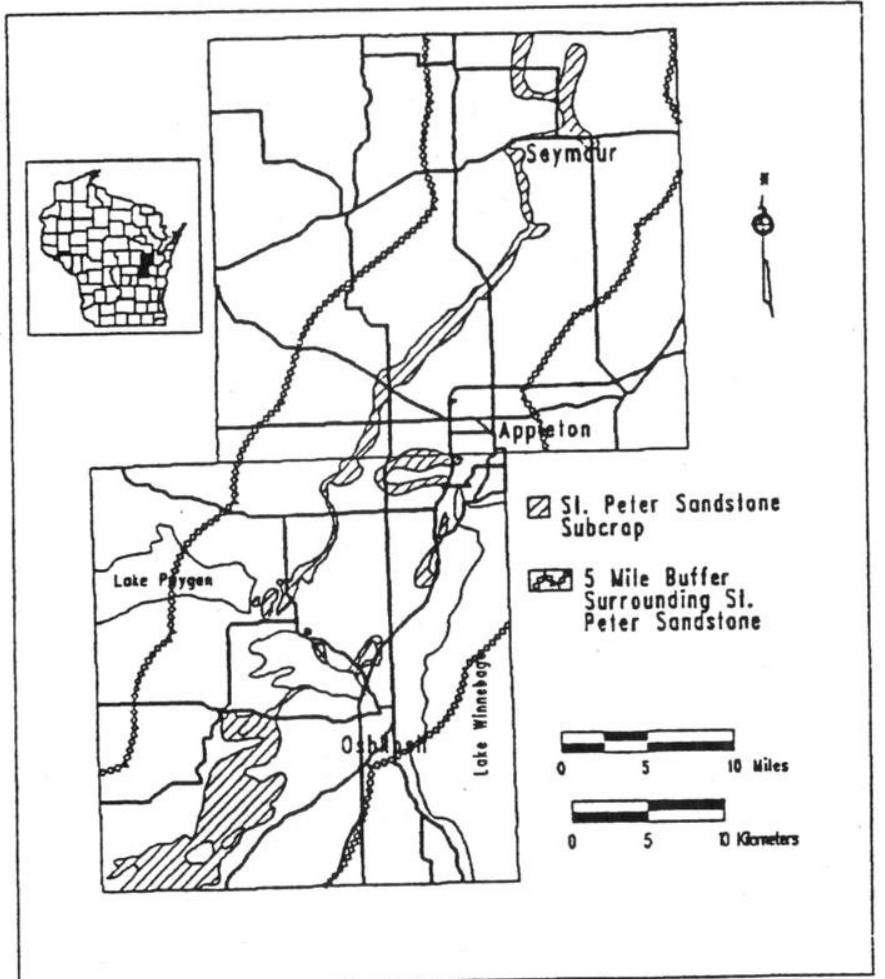

Fig. 2. Subcrop of St. Peter Sandstone Formation with five mile buffered odvisory orea overlaid on state highway network for Outagamie and Winnebago Counties. 
water. While depth of most private wells in Outagamie and Winnebago Counties typically range between $36.6 \mathrm{~m}$ to $48.8 \mathrm{~m}$ (120 to $160 \mathrm{ft}$ ) below surface, both Well 5 and Well 1 were unusually deep, allowing access to more subsurface formations. These wells also contained high arsenic concentrations in the water. Furthermore, the family drinking water from Well 1 stated, their physician informed them they exhibited symptoms associated with chronic arsenic poisoning.

\section{Well 5 - Water Quality Packer Test}

Well 5 is located in Outagamie County, Greenville Township. The original well was constructed in 1969 to a depth of $36.6 \mathrm{~m}$ (120 ft). According to the owner the well was reconstructed in 1990 to the depth of $97.8 \mathrm{~m}$ (321 ft). However, a well reconstruction form was not filed by the well driller thus, no subsurface information about the well was available beyond $36.6 \mathrm{~m}(120 \mathrm{ft})$ the original well depth.

In addition to elevated As and Fe levels. Well 5 also had an unusually low field $\mathrm{pH}$ of 4.3. The normal pH range for groundwater is between 6 and 8 . A pH of 4.3 is very acidic for well water and is likely a contributing factor for the increased arsenic and iron concentration here. Acidic water can corrode a plumbing system, oxidizing metals associated with pipes into soluble forms and thus into the water supply. Acidic water also will generally increase the solubility of some minerals within an aquifer thus incorporating metal ions into the water supply.

A caliper log, and gamma-ray log were run on Well 5 because the well had no subsurface information available below $36.6 \mathrm{~m}(120 \mathrm{ft})$. The packer test was used to determine specific zones within the Platteville/Galena, St. Peter Sandstone, and Prairie du Chien formations that would yield adequate water quality and quantity for potable use.

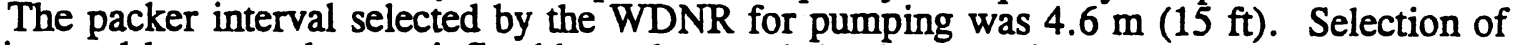
the interval between the two inflatable packers and the depth settings of the packers within the well column were based on the original well construction report and a gamma-ray log conducted with the intention of isolating discrete geologic layers contributing water to the well.

To minimize costs packer test intervals were selected which would best define vertical variations in arsenic concentration throughout the entire well column with the fewest number of packer tests. The contact between the Platteville/Galena and the St. Peter Sandstone formations, the zone thought to contribute relatively high arsenic concentrations to the water, could not be packed off to obtain a water sample because of undocumented well reconstruction which extended the casing to $27.4 \mathrm{~m}(90 \mathrm{ft})$. Therefore, this casing extended just beyond the formation contact and was a physical impairment to a packer test straddling the contact.

Due to the type of packer assembly used at Well 5, the integrity of the bottom packer seal could not be monitored. During each of the packer test intervals at the Well 5 site, there were no fluctuations in water levels above the packer assembly which suggests the upper packer was sealed properly.

\section{Well 1 - Water Quality Packer Test}

The second packer test was performed about $24.1 \mathrm{~km}(15 \mathrm{mi})$ away on Well 1 located in Outagamie County, Osborn Township. The original well borehole was constructed in 1984 to a total well depth of $30.8 \mathrm{~m}$ (101 ft). In March of 1993, the well was reconstructed to the depth of $91.4 \mathrm{~m}$ (300 ft). Drill cuttings from the reconstruction of the well were obtained by a WDNR representative. The Cambrian sandstone was encountered at $70.1 \mathrm{~m}(230 \mathrm{ft})$; the overlying Prairie du Chien dolomite was absent.

Well 1 was first sampled in 1992, due the owners complaint of an iron problem. The well was sampled for both iron and arsenic because the well was located near the St. Peter Sandstone trend. Initial test results revealed a very high iron concentration $(87 \mathrm{mg} / \mathrm{l})$ and an 
arsenic concentration of $1200 \mu \mathrm{g} / \mathrm{L}$, the highest arsenic concentration recorded at that time in a private water supply well in Outagamie County. Two months later a follow up water sample was collected and analyzed for arsenic, cadmium, chloride, chromium, conductivity, $\mathrm{pH}$, alkalinity, barium, calcium, copper, iron, magnesium, sodium. zinc, hardness, lead, nitrate + nitrite-nitrogen, selenium, silver, sulfate, total solids, field $\mathrm{pH}$, and field temperature. Both the field $\mathrm{pH}$ and $\mathrm{lab} \mathrm{pH}$ indicated normal ranges for groundwater. The levels of the other metals present in the water supply are abnormally high for well water.

The results from this sampling indicated that arsenic and cadmium exceeded the EPA Safe Drinking Water Act (SDWA) maximum contaminant levels (MCL). Also iron, manganese, zinc, and sulfate exceeded the SDWA secondary standards set by the EPA. Furthermore, these results indicated the need to analyze the packer test samples not only for arsenic but for cadmium, iron, manganese, zinc and sulfate to further delineate the zones of poor water quality.

The packer test was then designed to determine specific zones within the Platteville/Galena, St. Peter Sandstone, and the Cambrian sandstones that would yield adequate water quality and quantity for potable use.

The packer test interval selected by the WDNR was $9.1 \mathrm{~m}(30 \mathrm{ft})$. Selection of the interval between the two inflatable packers and the depth settings of the packers within the well column were based on the original well construction report, the drill cuttings collected, and the packer assembly. The design of the packer assembly at the Well 1 site, allowed monitoring the integrity of both packer seals. Water samples were only collected from the packer tests that had confirmed the integrity of packer seals by water level measurements above and below the packer assembly with little fluctuation during pumping. Each interval was pumped for approximately 10 minutes at $37.8 \mathrm{~L} / \mathrm{min}(10 \mathrm{gpm})$ so that a representative water sample could be obtained from each interval.

\section{Packer Testing - Water Sample Collection and Analysis}

The water samples were collected according to WDNR guidelines. All bottles, preservation methods, and labeling methods used were those required by the WSLH. Packer test water samples were collected from a brass tap located directly above the packer assembly prior to disposal to a holding tank. All water samples were sent to WSLH for appropriate chemical analysis.

All packer test water samples were taken after 10 minutes of pumping at 10 gallons per minute, (gpm), from the isolated interval. This was done to obtain a representative in situ sample of groundwater from the interval within the aquifer. Water from each packer test was tested for field $\mathrm{pH}$, field temperature. The water sample was then filtered using a .45 micron filter prior to being sent to the WSLH for analysis of arsenic, cadmium, copper, manganese, and zinc.

\section{Drill Cutting Analysis}

Drill cuttings were used to determine zones where mineral dissolution could contribute to poor water quality. In conjunction with a lithological summary, the drill cutting analysis aided in determining zones within the subsurface containing relatively higher concentrations of naturally occurring arsenic. Drill cutting samples were collected as grab samples from the rotary drill stem return flow from seven different wells located in Outagamie and Winnebago Counties. Trace metal analysis was performed on all these wells in an attempt to correlate areas of high arsenic concentrations with specific geologic strata. These data were used to confirm conclusions drawn from packer testing. Wells were chosen for drill cutting analysis based upon the availability of drill cuttings and location. The methods and results for three representative wells follow in a more detailed discussion. 
Drill Cutting Collection and Analysis

Well 7, Well 6, and Well 1

Drill cutting samples from Well 7 were collected in 1946 either by the well driller or by the Wisconsin Geological and Natural History Survey (WGNHS) and stored in the WGNHS repository. Records of collection methods were not available. Samples obtained from the repository were identified at $1.5 \mathrm{~m}(5 \mathrm{ft})$ intervals throughout the entire well. At the request of the WDNR, a portion of the drill cuttings were sent to WSLH for digestion and arsenic analysis. The well driller collected drill cuttings from Well 6 for each $1.5 \mathrm{~m}(5 \mathrm{ft}$.) interval, in cloth bags provided by WGNHS. The drill cuttings were forwarded to WSLH for digestion and arsenic analysis.

The drill cuttings from Well 4 were collected at the time of well construction in 1993. Drill cutting samples were collected at five-foot intervals throughout the entire well column, labeled and stored in cloth bags.

From each well, only selected intervals were analyzed because limited funding prohibited the analysis of all samples collected. The overburden material in each well was not analyzed because the overburden generally does not provide water to Outagamie and Winnebago County private well owners. Thus most private wells in Outagamie and Winnebago County draw water from the underlying formations, which include, the Platteville/Galena Formation, the St. Peter Sandstone, the Prairie du Chien Group and/or the Cambrian sandstones. Therefore selected intervals for arsenic drill cutting analysis were from the Platteville/Galena Limestone, St. Peter Sandstone, Prairie du Chien group and Cambrian sandstones.

The collected drill cutting samples were split and a portion of the drill cuttings from each well was sent to WGNHS for lithological study and repository retainment. The remaining portion was prepared for arsenic analysis and sent to the University of Wisconsin Soil and Plant Analysis Lab in Madison, Wisconsin, to be analyzed.

Prior to shipment for laboratory analysis all drill cutting samples were carried through the following procedure for digestion at the University of Wisconsin - Green Bay. Each sample was initially prepared by placing in a plastic vegetable-strainer and rinsing with distilled water to remove the drilling mud from the sample. Rinsing continued until no fine particulates were observed in the distilled water. The samples were allowed to dry and then placed in a labeled plastic container.

Ultrapure nitric acid $\left(\mathrm{HNO}_{3}\right)$ was added to 1.5 to $2.0 \mathrm{~g}$ samples. Ultrapure nitric acid was utilized in the digestion because analytical reagent grade nitric acid contains detectable quantities of trace metals. The sample material was heated and dissolved in the acid for at least 15-20 minutes. Any remaining undissolved matter remaining in the flask was assumed to be insoluble silicate minerals. All flasks had some insoluble material present after digestion. It was thought unnecessary to dissolve the remaining material in the flask, because if the material had not dissolved in the nitric acid it would not dissolve in groundwater. The undissolved material, therefore would likely not play a significant role in arsenic contribution in the groundwater supply. After cooling, transferring, and dilution the thirty samples were sent to the University of Wisconsin Plant and Soils Laboratory in Madison, Wisconsin for analysis by Inductively Coupled Plasma and Mass Spectrometry (ICP-MS) for arsenic. Included with these samples were a blank and a duplicate which had been prepared utilizing the same rigid quality control procedures. 


\section{RESULTS and DISCUSSION}

\section{Private Well Arsenic Levels}

Locations of sampled wells with elevated arsenic concentrations for Outagamie and Winnebago counties are shown in figures 3 and 4 respectively. A general trend of elevated arsenic concentrations are clustered within a five mile buffered strip surrounding the St. Peter Sandstone trend which extends northeast throughout both counties. Most elevated arsenic concentrations in private water supplies in both counties lie to the east of the mapped St. Peter Sandstone trend. This is where the St. Peter Sandstone is presumably the aquifer supplying private wells.

There are, however, some areas where wells with elevated arsenic concentrations lie west of the mapped St. Peter Sandstone trend. This is unexpected if the St. Peter Sandstone trend is the primary source of naturally occurring arsenic in the groundwater. One hypothesis for high levels of arsenic west of the St. Peter Sandstone trend is the sandstone lenses of the Prairie du Chien or the sandstone of the Cambrian formation rather than only the St. Peter formation contribute arsenic to well water. A second more likely hypothesis for the appearance of elevated arsenic in water from wells west of the erosional edge of St. Peter Sandstone is that the bedrock map for this area exhibits inferred St. Peter Sandstone subcrop contacts because there was not enough data to map it accurately. These inferred areas correspond to the areas where wells with elevated arsenic concentrations exist to the west of the mapped subcrop and suggest that the St. Peter Sandstone subcrop may be incorrectly mapped in certain areas.

The reasons for arsenic contamination just west of the St. Peter Sandstone subcrop should be further studied. This information would help well drillers reduce the likelihood of arsenic contamination when constructing new wells within the advisory area.

The geology of Winnebago county is quite similar to that of Outagamie County. Winnebago County had 23 wells of 827 wells sampled that exceeded the health advisory standard for arsenic while Outagamie County exhibited 45 of 1116 wells over the standard. A general trend from the plot of arsenic contamination and geology shows that wells with elevated levels of arsenic were found principally in areas where St. Peter Sandstone is present, based on existing bedrock geology maps. This is particularly true if one selects an arbitrary value of $5 \mu \mathrm{g} / \mathrm{L}$ arsenic and examines its presence in wells sampled as related to geology. The greatest predominance of arsenic is found where the St. Peter Sandstone is present.

The distribution of arsenic concentrations found in Outagamie and Winnebago Counties is found in Table 1. This figure indicates that 68 of 1943 samples $(3.5 \%)$ exceeded the NR 140 Wisconsin Administrative Code of $50 \mu \mathrm{g} / \mathrm{L}$ As. This level is also the US EPA drinking water standard. When well water exceeded this level a health advisory was issued to the residents. Furthermore, $5 \mu \mathrm{g} / \mathrm{L}$ arsenic was exceeded in $32 \%$ of the wells sampled throughout both counties combined.

The distribution of water well arsenic concentrations in Brown, Shawano, Oconto and Marinette Counties is markedly different (Tables 2 and 3). Arsenic appears to be a localized problem in parts of Brown County where 18 of 76 sampled wells exceeded the EPA drinking water standard. Seventeen of these exceeding wells are located within the same square mile or town, range and section. This enclave of exceeding wells is surrounded by an area of municipal water service such that additional expanded nearby water sample collection locations are limited. However, an additional well about two miles away also exhibits arsenic exceeding the EPA MCL. One well exhibited field $\mathrm{pH}$ measurements as low as 3.1.

The sample information for Shawano, Oconto and Marinette Counties indicate this more northern group of counties is much less likely to exhibit arsenic related drinking water problems (Figure 5). While the same geologic trend was similarly sampled there were no 


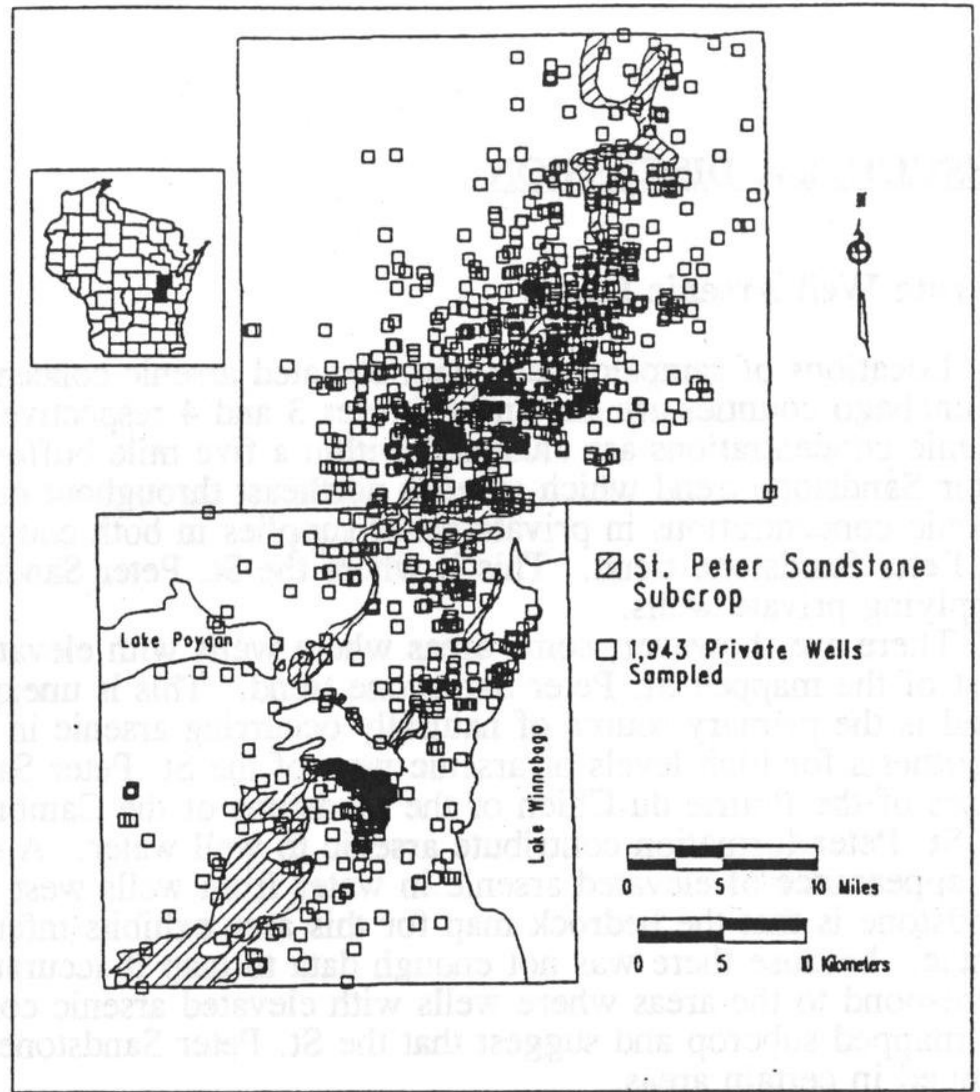

Fig. 3. Privote wells sampled and superimposed on St. Peter Sandstone trend across Outogamie and Winnebogo Counties.

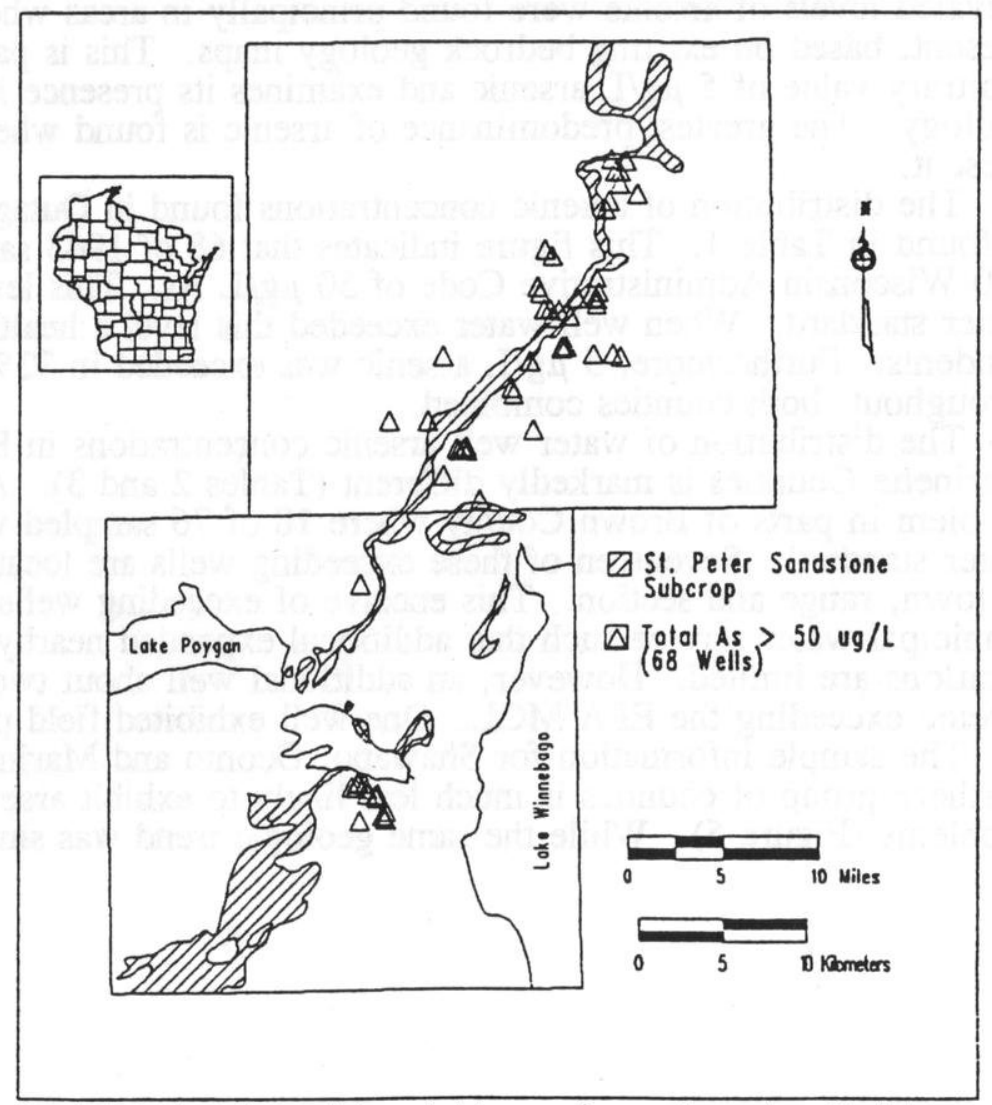

Fig. 4. Private wells most impocted by orsenic superimposed on St. Peter Sandstone trend for Outogamie and Winnebogo Counties. 
drinking water standard exceedences. Although 15 of 106 sampled wells exceeded $5 \mu \mathrm{g} / \mathrm{l}$ arsenic, this is remarkably lower than arsenic concentration expectations presented for Outagamie, Winnebago and part of Brown County.

The presence of a significant relationship existing between wells exceeding the arsenic health advisory and specific geologic strata was investigated by seeking well construction reports which exhibited sandstone. Of the 1943 private wells sampled in Outagamie and Winnebago Counties, 751 or $39 \%$ of the well construction reports were found. The construction report contains the depth of the well, the casing depth, geologic strata encountered and other well information reported by the driller at the time of construction. Most well construction reports could not be located due most often to errors in either the original well location or the well driller's failure to file the form.

There are many problems encountered when using well construction reports for information because they are often inaccurate or unavailable. WGNHS reports that greater than 10 percent of the reports submitted within the last few years have incorrect or vague information (WGNHS, 1991). Unfortunately, sufficient accurate reports were not available, however they could have further helped discriminate the source of naturally occurring arsenic.

The results from the Well 5 packer test indicated that the arsenic concentration found throughout the entire well column remained above the health advisory level of $50 \mu \mathrm{g} / \mathrm{L}$. The arsenic concentration was the highest $(>1,000 \mu \mathrm{g} / \mathrm{L})$ at the contact between the Prairie du Chien and the Cambrian sandstones $(83.2 \mathrm{~m}$ to $87.8 \mathrm{~m})(273 \mathrm{ft}$ to $288 \mathrm{ft}$ ) (Figure 6). However, this concentration likely resulted from the excessive sediment found in this zone. The bottom $6.1 \mathrm{~m}(20 \mathrm{ft})$ of the well was filled in with sediment. During the packer test, sediment probably from the bottom of the well column, was drawn up through the pump and into the sample. In fact, sediment clogged the pump during the packer test and stopped it. Head monitoring was not possible below the bottom packer, indicating the bottom packer probably had a faulty seal resulting in sediment being incorporated into the sample. Even though the sample was filtered the WSLH noted abundant colloidal material which was acidified and analyzed with the sample. The sediment at a well bottom is not normally incorporated into the water supply, as the pump is set far above it. However, in this case the packer assembly was dropped right into the sediment likely stirring the sediment, reducing the seal and incredibly blackening the water with suspended and colloidal material. Even though the sample was filtered, the remaining dissolved sample exhibited cloudy material. Elsewhere throughout the well column arsenic concentrations were highest in the upper portions of the St. Peter Sandstone $(610 \mu \mathrm{g} / \mathrm{L})$. Arsenic concentrations declined to 51 $\mu \mathrm{g} / \mathrm{L}$ at the bottom of the St. Peter Sandstone. This trend correlates with the findings from drill cutting analysis (described later) which also showed a marked increase in arsenic concentrations in the upper portions of the St. Peter Sandstone compared to levels in the bottom of the St. Peter Sandstone. The packer test results show the arsenic concentration increasing in the Prairie du Chien dolomite $(55.8 \mathrm{~m}$ to $75.6 \mathrm{~m})(183 \mathrm{ft}$ to $248 \mathrm{ft})$. This trend was somewhat puzzling because it does not correlate with other analytical results for As from drill cuttings. Drill cutting analysis of the Prairie du Chien dolomite suggests that it has low concentrations of arsenic within it. In fact, a new replacement potable well has since been drilled on this property approximately $30.5 \mathrm{~m} \mathrm{(100} \mathrm{ft)} \mathrm{away} \mathrm{and} \mathrm{is} \mathrm{cased} \mathrm{into} \mathrm{the} \mathrm{Prairie} \mathrm{du}$ Chien dolomite. This well draws water from that dolomite and the underlying Cambrian sandstone and has tested to be below $2.2 \mu \mathrm{g} / \mathrm{L}$ As. Therefore, other factors such as available oxygen (discussed later) may play an important role.

High arsenic concentrations appear to correlate with low field $\mathrm{pH}$ values. Also, other high metal concentrations ( $\mathrm{Cd}, \mathrm{Fe}, \mathrm{Mn}, \mathrm{Cu}$, and $\mathrm{Zn}$ ), even though not determined on all samples, seem to correlate with the arsenic levels observed at this location. It appears that as the $\mathrm{pH}$ decreases the metal ion concentrations in the groundwater increase. Low $\mathrm{pH}$ values may increase metal ions concentrations by dissolving metallic minerals in the aquifer.

Iron concentrations found in the packer test intervals exceeded the EPA SDWA

Secondary standard for iron of $0.3 \mathrm{mg} / \mathrm{L}$. Iron concentrations exceeding the standard 


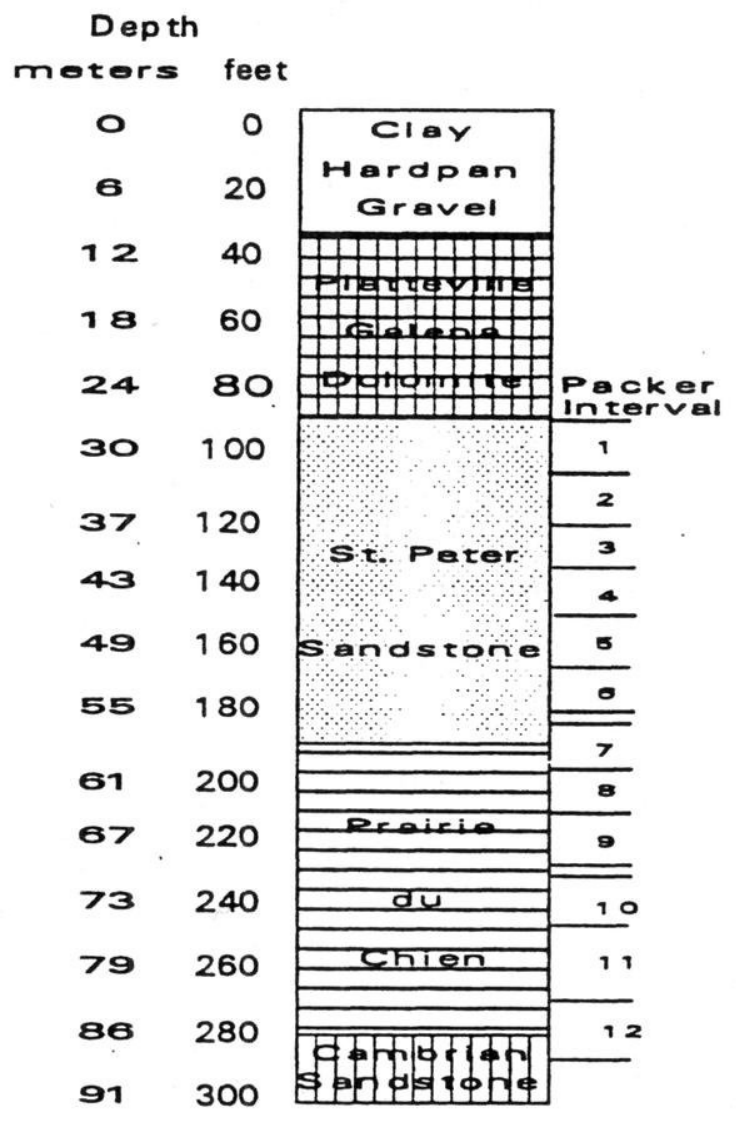

\begin{tabular}{|c|c|c|c|c|c|c|c|}
\hline \multirow{2}{*}{$\begin{array}{l}\text { Packer } \\
\text { Interval }\end{array}$} & \multicolumn{7}{|c|}{ Concentration ug/L } \\
\cline { 2 - 8 } & As & Fe & Cd & Zn & Mn & Cu & pH \\
\hline & & & & & & & \\
\hline 1 & 610 & 450000 & 1500 & 3000 & 3000 & 650 & 2.8 \\
\hline 2 & 450 & & & & & & 3.5 \\
\hline 3 & 360 & & & & & & 5.2 \\
\hline 4 & 230 & 160000 & 270 & 14000 & 1000 & 95 & 6.1 \\
\hline 5 & 72 & & & & & & 6.5 \\
\hline 6 & 51 & 79000 & 17 & 2500 & 500 & 41 & 6.6 \\
\hline 7 & 250 & & & & & & 6.1 \\
\hline 8 & 360 & & & & & & 5.5 \\
\hline 9 & 400 & 260000 & 75 & 13000 & 1700 & 40 & 5.4 \\
\hline 10 & 370 & & & & & & 5.2 \\
\hline 11 & No Water & & & & & & \\
\hline 12 & 1000 & 460000 & 690 & 35000 & 1700 & 5300 & 5.8 \\
\hline
\end{tabular}
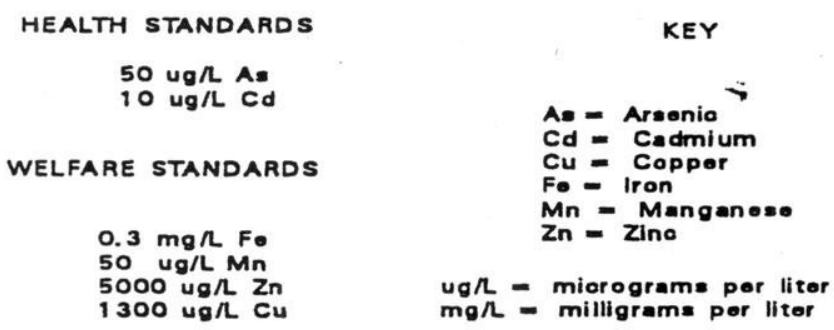

Figure 6. Well number 5 packer test results. 
typically cause aesthetic nuisance problems such as odor and staining. In addition, cadmium levels exceeded the health advisory of $10 \mu \mathrm{g} / \mathrm{L}$ in all of the packer intervals analyzed for cadmium. Copper concentrations exceeded the health advisory of $1300 \mu \mathrm{g} / \mathrm{L}$ in only one of the packer test intervals. This interval was the bottom one which contained large amounts of sediment and colloidal material in the sample. Some of this material did not filter out with .45 micron filtering. Manganese concentrations remained over the EPA SDWA Secondary Standard of $50 \mu \mathrm{g} / \mathrm{L}$ in all of the packer intervals selected to be analyzed. Zinc concentrations exceeded the EPA SDWA Secondary Standard of $5000 \mu \mathrm{g} / \mathrm{L}$ in all but one of the packer intervals tested. In addition to excessive suspended sediments the low pH provides an answer as to why there is excessive amounts of these metals present in the water supply.

The low $\mathrm{pH}$ found in Well 5 , is significantly different from neighboring wells surrounding Well 5. Two wells in Outagamie County (Wells 2 and 3) are also known to have low pH. Well 2 located in Outagamie County, Oneida Township, has an abnormally low $\mathrm{pH}$ of 2.5 . Arsenic, iron, cadmium and lead (5,900,740, 210, $160 \mathrm{mg} / \mathrm{l}$, respectively) were all excessively elevated in that well water. Also, through extensive case investigation by use of geophysics, boring, and monitoring well installation, the WDNR has determined this $\mathrm{pH}$ is of natural origin by pyrite oxidation. A new well has been drilled on this property which draws water from the Galena dolomite and has an arsenic value of $4 \mu \mathrm{g} / \mathrm{L}$ and a pH of 8.22 SU. Wells surrounding Well 2 were also sampled and analyzed for $\mathrm{pH}$, however, these were not anomolous. The original Well 3 was located within one mile of Well 5 located in Outagamie County, Greenville Township, and was found to also have a pH of 3.0 in 1967. Other nearby wells were sampled and did not exhibit similar low $\mathrm{pH}$ values at that time. Similar to the other occurrences of low pH, an anthropogenic source could not be located. A new well was drilled to provide potable water with a $\mathrm{pH}$ between $6.0-9.0$. However a new well construction form was not completed by the driller.

The Well 5 packer test results showed that the $\mathrm{pH}$ in the well varied throughout the well column. This data suggests the source of the low $\mathrm{pH}$ is at the top of the St. Peter Sandstone formation where the PH was 2.8. Water from the upper portion of the St. Peter Sandstone contained substantially lower $\mathrm{pH}$ than that of lower portions of the well. Groundwater associated with low pH may contain free-mineral acid from mine water, volcanic gases or contaminants by man-made sources (Driscoll, 1986). It is likely that the acidic nature of the Well 5 water is derived from minerals within the St. Peter Sandstone that have oxidized forming sulfuric acid. Anthropogenic sources for this problem are ruled out due to its geographic breadth, the presence of other wells known to have low $\mathrm{pH}$ 's, and the Well 5 packer test results which show dramatic changes in well water $\mathrm{pH}$ at different depths. Many wells in the study area which exhibit elevated arsenic concentrations may not have significantly measurable $\mathrm{pH}$ differences as the $\mathrm{pH}$ would be diluted throughout the water within the entire well column. A packer test such as that performed at the Well 5 location would be necessary to isolate the rock band contributing acidic mineralized water to the well. Only a few natural reactions are known to cause low $\mathrm{pH}$ in groundwater. Driscoll (1986) mentions that the acids from mine waters tend to derive from the oxidation of iron pyrite or other metal sulfide minerals to form sulfuric acid $\left(\mathrm{H}_{2} \mathrm{SO}_{4}\right)$. The unbalanced chemical reaction sequences occurring in acids from mine waters causing $\mathrm{pH}$ values as low as 2 taken from Manahan, 1991 are:

Oxidation of Sulfide in Pyrite or Marcasite Occurring in the Presence of Water $2 \mathrm{FeS}_{2 \mathrm{E}}(s)+2 \mathrm{H}_{2} \mathrm{O}+7 \mathrm{O}_{2} \stackrel{2}{\longrightarrow} 4 \mathrm{H}^{+}+4 \mathrm{SO}_{4}{ }^{2-}+2 \mathrm{Fe}^{2+}$ Oxidation of Ferrous Ion to Ferric Ion $4 \mathrm{Fe}^{+2}+\mathrm{O}_{2}+4 \mathrm{H}^{+} \longrightarrow 4 \mathrm{Fe}^{3+}+2 \mathrm{H}_{2} \mathrm{O}$ Ferric Ion Further Dissolves Pyrite

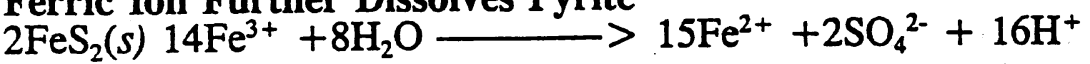


Pyrite and marcasite are known to exist at least in trace quantities within the Platteville/Galena Dolomite and St.Peter Sandstone from drill cutting lithology reports. Oxidation of these trace quantities of pyrite and marcasite does contribute to the acidic nature of the groundwater (Bierens de Haan, 1991). Even the simple placement of a marble size field sample in $250 \mathrm{ml}$ of distilled water reduced the $\mathrm{pH}$ from 7.0 to 2.0 overnight. Oxidation of pyrite, also, may cause elevated levels of arsenic in groundwater because arsenic tends to be associated with sulfide minerals with pyrite as one of its principal constituents. Arsenic can be used as an indicator of the following types of deposits: $\mathrm{Cu}, \mathrm{Ag}$, $\mathrm{Au}, \mathrm{Zn}, \mathrm{Cd}, \mathrm{Hg}, \mathrm{U}, \mathrm{Sn}, \mathrm{Pb}, \mathrm{P}, \mathrm{Sb}, \mathrm{Bi}, \mathrm{S}, \mathrm{Se}, \mathrm{Te}, \mathrm{Mo}, \mathrm{W}, \mathrm{Fe}, \mathrm{Ni}, \mathrm{Co}$, because it is often associated with them. Arsenic is commonly found in certain types of mineral deposits, especially with the metals $\mathrm{Cu}, \mathrm{Ag}, \mathrm{Zn}, \mathrm{Hg}, \mathrm{Pb}$, and $\mathrm{Fe}$ (Boyle and Jonasson, 1973).

Marcasite and pyrite occur in abundant quantities in a rock core through the upper St. Peter Sandstone which was obtained from Well 2. Laboratory analysis of the sulfide rock material obtained from these Well 2 location cores showed arsenic was present at $150 \mathrm{mg} / \mathrm{kg}$. However, pyrite within lenses or fractures existing in the subsurface may exist in larger quantities than mentioned in a lithology report because of the problems obtaining representative cuttings samples. These lenses may be important since trace quantities of pyrite are known to exist in other wells that have no $\mathrm{pH}$ problems. Preliminary investigations surrounding Well 2 (described earlier) show corings from the contact between the Platteville/Galena and the St. Peter Sandstone contained pyrite and marcasite. It is plausible that these minerals may also be found in larger lenses or fractures of adjacent rock.

The reaction for marcasite and pyrite is similar. The initial oxidation of sulfide in pyrite requires oxygen and is slow. Once this oxidation is initiated releasing ferrous iron and sulfate the reaction may be catalyzed by iron-oxidizing bacteria even at very low oxygen concentrations. The iron bacterium Thiobacillus ferrooxidans may catalyze the reaction below pH of 3.5 (Manahan, 1991). Within the $\mathrm{pH}$ range of 3.5 and 4.5 the reactions may be catalyzed by filamentous iron bacterium (Metallogenium) (Manahan, 1991). Other bacteria that may participate in catalyzing these chemical reactions are Thiobacillus thiooxidans and Ferrobacillus ferrooxidans (Manahan, 1991).

This is significant since these chemical reactions are mediated and often catalyzed by these microorganisms mentioned previously. This given chemical reaction sequence requires the presence of oxygen. Oxygen may be provided to the iron-rich water flowing from the aquifer by frequent pumping and the presence of the open well column itself, by air rotary drilling or may be provided at the well/rock interface where oxygen may be present (Smith and Tuovinen, 1985).

The presence of high concentrations of iron and sulfate suggest that the acidic nature of both wells may have been derived from a natural source, possibly, the oxidation of pyrite or marcasite. Groundwater that contains high dissolved iron concentrations often can be related to the oxidation of reduced iron minerals (Smith and Tuovinen, 1985).

Highly acidic environments in aquifers are rare with exception of those environments contaminated with acid mine drainage or acidophilic bacteria. Both acid mine drainage and acidophilic bacteria usually do not occur in water wells (Smith and Tuovinen, 1985).

Therefore, not much is known about the bacterial catalyzed oxidation of iron in groundwater and water wells (Smith and Tuovinen, 1985). Wells with pH values as low as Wells 5, 2 and 3 are rare. The origin of the acidic nature of well water needs further study.

The results of water samples collected from the packer test intervals at Well 1 follow in Figure 7. These analytical results show a general decline in arsenic concentrations with depth within the well column. All of the water samples collected from the packer test intervals indicate a significant reduction in arsenic concentration from that of the original shallower well. Two water samples from the original well had arsenic concentrations of $1200 \mu \mathrm{g} / \mathrm{L}$ and $720 \mu \mathrm{g} / \mathrm{L}$. The upper portion of the St. Peter Sandstone [34.7 m to $43.9 \mathrm{~m}$ $(114 \mathrm{ft}$ to $144 \mathrm{ft}$ )] exhibits higher arsenic concentrations than those found in the base of the St. Peter Sandstone [ $43.9 \mathrm{~m}$ to $62.2 \mathrm{~m}$ (144 ft to $204 \mathrm{ft})$ ] and in the Cambrian sandstones [71.3 $\mathrm{m}$ to $91.4 \mathrm{~m}$ (234 $\mathrm{ft}$ to $300 \mathrm{ft})]$ found below it. While arsenic concentrations within 


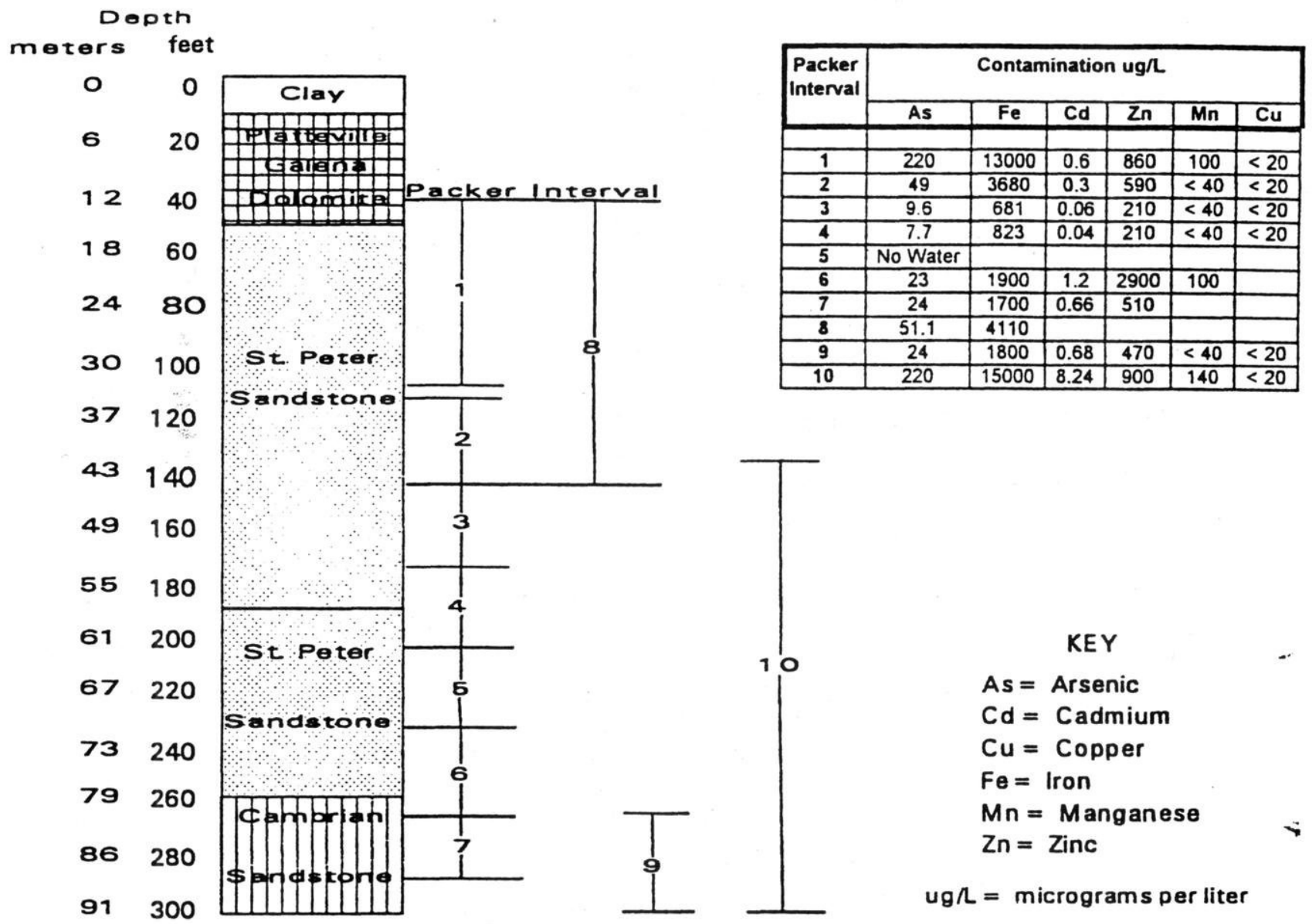

Figure 7. Well number 1 packer test results. 
the water column increase in the Cambrian sandstones, they were below the current health standard $(50 \mu \mathrm{g} / \mathrm{L})$ and much below the concentration found in the upper St. Peters Sandstone.

Iron concentrations follow the same trend as the arsenic trend, with higher concentrations noted in the upper St. Peter Sandstone. The iron concentration in the well water declines in the lower portion of the St. Peter Sandstone and then rises somewhat within the Cambrian sandstones. The iron concentration in the samples collected from the packer test remains above the EPA welfare standard $(0.3 \mathrm{mg} / \mathrm{l})$ throughout the entire well column. However, the iron concentrations are significantly reduced from that of the original well which had a iron concentration of $80 \mathrm{mg} / \mathrm{L}$.

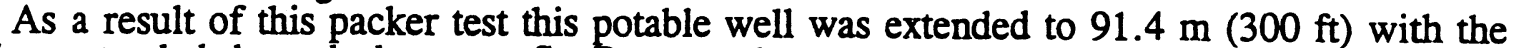
casing extended through the upper St. Peter sandstone to $45.7 \mathrm{~m}(150 \mathrm{ft})$. The resulting As concentration is $12 \mu \mathrm{g} / \mathrm{L}$, a substantial reduction from the original $1200 \mu \mathrm{g} / \mathrm{L}$ As.

\section{Drill Cutting Results}

Drill cuttings were collected for analysis from six well drilling locations across Outagamie and Winnebago Counties. All six locations were located in different townships stretched along roughly $56.3 \mathrm{~km}(35 \mathrm{mi})$ of the mapped St. Peter Sandstone subcrop trend. These locations were selected based upon drill cuttings availability and the expectation that the St. Peters Sandstone and adjacent geologic formations could be representatively sampled. The cuttings from three of the six wells sampled exhibited arsenic at greater than $15 \mathrm{mg} / \mathrm{kg}$. This concentration is significantly less than $40 \mathrm{mg} / \mathrm{kg}$ identified as the top end of the typical range for concentrations found nationally in soils (Dragun, 1988). The following describes the cutting results from these three wells with arsenic concentrations above this value.

\section{Well 7 - Drill Cutting Results}

Well 7, located in Winnebago County, Vinland Township, was constructed in 1946 to a depth of $166.1 \mathrm{~m}$ (545 ft). Thirty-five drill cutting samples from Well 7 were analyzed for arsenic (Figure 8 ). The results indicated a relatively higher arsenic concentration within the St. Peter Sandstone relative to the overlying Platteville/Galena Dolomite. The underlying Prairie du Chien Dolomite, however, had higher arsenic concentrations. These were within zones of the formation composed of sandstone versus zones composed of dolomite. The deeper Cambrian Sandstones contained higher levels of arsenic than those found in the St. Peters Sandstone. The Cambrian Sandstone arsenic concentrations were slightly lower than those found in the sandy facies of the Prairie du Chien. Thus, the Prairie du Chien and Cambrian Sandstone units may also be suspected to contribute arsenic to groundwater. However oxygen availability is likely minimal since the static water level is at least $45.4 \mathrm{~m}$ (149 ft.) above these lithologies. This well was sampled in 1988 for arsenic at which time it was not detected.

\section{Well 6 - Drill Cutting Results}

The second well was located in Winnebago County, Clayton Township and was drilled in April of 1990 to a depth of $41.1 \mathrm{~m}(135 \mathrm{ft})$. These drill cutting results (Figure 9) show arsenic concentrations to be relatively higher in the St. Peter Sandstone than in other formations comprising the well. This observation is consistent with data obtained from packer testing and drill cutting analysis at other sites. The upper Prairie du Chien unit also shows relatively higher arsenic concentrations than those found in the Platteville/Galena Dolomite. The relatively low arsenic concentration found at the contact between the St. Peter Sandstone and the basal Platteville/Galena Dolomite may be due to the sampling method. For any grab sample from a $1.5 \mathrm{~m}$ (5 ft.) drilling interval it is typical that only 2 to $3 \mathrm{~g}$ of sample are chemically analyzed. This problem can occur for any grab sampling 
event. A grab sample may have been taken when the well driller began drilling at $35.1 \mathrm{~m}$ $(115 \mathrm{ft})$. If this were the case, it would have been a sample from the Platteville/Galena Dolomite and not the contact zone. The water sample from this well exhibited arsenic at $8.5 \mathrm{mg} / 1$ in 1992 .

\section{Well 4 - Drill Cutting Results}

This third private well located in Outagamie County, Greenville Township was constructed in October 1992 to a total depth of $49.1 \mathrm{~m}(161 \mathrm{ft})$. The drill cutting analytical results in Figure 10 indicate arsenic concentrations are noticeably higher at the top of the Cambrian Sandstone. Various other intervals within the well column were not analyzed due to cost constraints. Both $\mathrm{Ag}$ and $\mathrm{Pb}$ also showed positive high correlations with Arsenic in the drill cuttings. A water sample result is not available from this well.

\section{Data Interpretation}

The private wells sampled in this study show 45 of 1116 wells sampled in Outagamie County exceed the health advisory for arsenic. Similarly 23 of the 827 wells sampled in Winnebago County exceeded the health advisory for arsenic. The arsenic health advisory was exceeded in 18 of 76 wells in Brown County. This advisory level was not exceeded in any of 105 wells sampled in the more northerly counties of Shawano, Oconto or Marinette. Due to the similarity of the bedrock geology, groundwater flow and the number of samples exceeding the health advisory, interpretation of the arsenic contamination pattern in privates wells will be jointly addressed for Outagamie and Winnebago Counties.

Except in Brown County where wells are much deeper, the private wells exceeding the health advisory for arsenic tend to lie most commonly within a $8.0 \mathrm{~km}(5 \mathrm{mile})$ area of the St. Peter Sandstone subcrop as seen on Figure 2 and 4. The St. Peter Sandstone subcrop refers to the area where the St. Peter Sandstone is nearest to the surface. Since most private wells within the study area of Outagamie and Winnebago Counties range between $30.5 \mathrm{~m}$ and $48.8 \mathrm{~m}$ (100 and $160 \mathrm{ft}$ ) in total depth, the St. Peter Sandstone would be the strata most wells draw water from. Wells located outside this area-most likely would not draw water from zones within the St.Peter Sandstone because it would lie deeper than the other shallower aquifer zones or otherwise is non-existent. The St. Peter Sandstone dips to the southeast at a rate of $4.7 \mathrm{~m} / \mathrm{km}(25 \mathrm{ft} / \mathrm{mile})$ (Olcott, 1966). Those private wells located outside the $8.0 \mathrm{~km}$ ( 5 mile) boundary from the St. Peter Sandstone that are deeper than normal, however, may encounter the St. Peter Sandstone. This does occur in some private wells about $16.0 \mathrm{~km}(10 \mathrm{mi})$ eastward in adjacent Brown County where numerous wells sampled also exceed the As health advisory.

Wells with high arsenic levels may receive larger quantities of water from zones within the subsurface with higher arsenic mineral content. The upper member of the St. Peter Sandstone is known as the Glenwood Member This Member is known to be highly mineralized. Therefore, the water derived from this zone within the well may contain a higher arsenic content due to the dissolution of those minerals. Arsenic concentrations in the well water are the results of a complex interplay of minerals present in the aquifer supplying the water, the flow of water through the aquifer, the geochemistry of the groundwater, microorganisms present and a host of other geochemical conditions. Studies are continuing to address some of these factors.

To further rule out the possibility of multiple point sources as a reason for elevated arsenic levels in groundwater, a search for arsenic pesticide storage facility locations was undertaken. Arsenic-based pesticides, such as sodium arsenite, were used in the 1930's and 1940's in Wisconsin for grasshopper control. No anthropogenic sources were found that could possibly impact this many wells across $56.3 \mathrm{~km}$ (35 miles) linear distance paralleling the St. Peter Sandstone subcrop. 


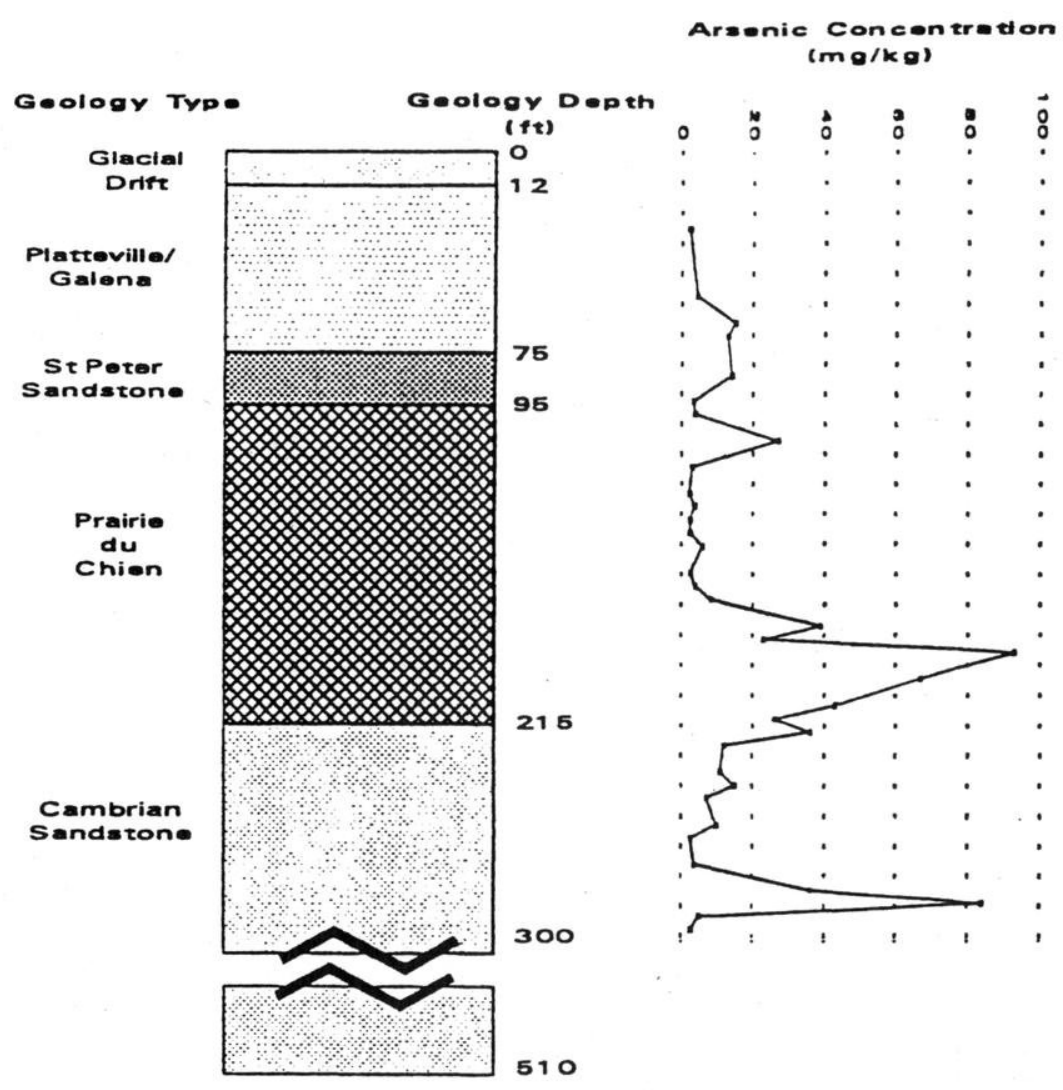

Figure 8. Drill Cutting Results for Well Number 7 .

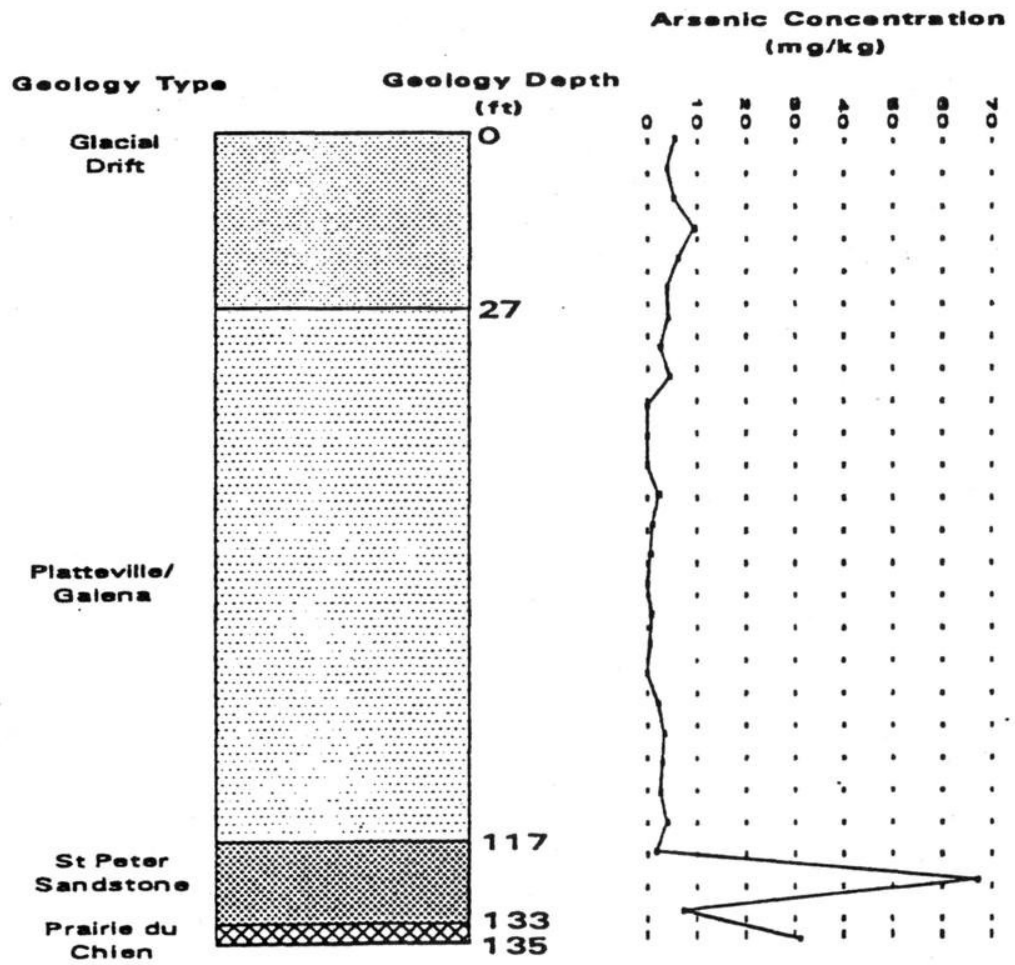

Figure 9. Drill Cutting Results for Well Number 6 . 
The drill cutting analysis is consistent with the theory that the arsenic in well water across both counties comes from natural sources. Although arsenic concentrations in the groundwater cannot be predicted from drill cutting results, a relative depth indicating where to expect high arsenic concentrations can be predicted. The drill cutting results suggest that higher arsenic concentrations should exist in the upper portions of the St. Peter Sandstone and possibly the lower portion of the overlaying Platteville/Galena Formation.

The drill cutting results are generally supported by the packer testing results. Even though the contact between the St. Peter Sandstone and the Platteville/Galena Formation was not directly tested, the packer tests showed a marked increase in arsenic concentration in the upper portion of the St. Peter Sandstone. The lower St. Peter Sandstone and the Prairie du Chien units had much lower arsenic concentration in the groundwater received from those aquifers. The results suggest that one should avoid extracting well water from the upper portion of the St. Peter Sandstone aquifer to minimize arsenic levels in groundwater supplies.

\section{New Well Construction and Well Reconstruction}

Arsenic contamination in private wells has been reduced to below drinking water standards primarily by constructing a new well or reconstructing an existing well. This has been successful in at least 15 out of 17 cases just by eliminating the upper St. Peter Sandstone as a primary water source, (Figure 11). In two cases the well was drilled shallower to draw water from the Platteville/Galena Dolomite only, thus removing the underlying St. Peter Sandstone as the source of water altogether. In the other cases, the wells were constructed deeper and the casing was extended beyond the upper St. Peter Sandstone preventing this zone from recharging the well. Some cases utilized water exclusively from the Prairie du Chien Dolomite. The other cases obtained water jointly from the Prairie du Chien Dolomite and the underlying Cambrian Sandstone. Each construction successfully reduced arsenic concentrations to significantly below the drinking water standards.

\section{CONCLUSIONS AND RECOMMENDATIONS}

This study of arsenic levels in private wells in Outagamie and Winnebago Counties has shown that a significant number of wells are affected by high arsenic levels. The present health standard of $50 \mu \mathrm{g} / \mathrm{L}$ As was exceeded in $3.5 \%$ of the wells tested. If the health advisory standard for arsenic is lowered to $5 \mu \mathrm{g} / \mathrm{L}$ as has been indicated in the environmental community, then the percentage of the wells affected will increase to $32.0 \%$.

Computer mapping utilizing a Geographic Information System (GIS) proved to be a valuable tool to identify the approximate geographic regions in Outagamie and Winnebago Counties where private wells are affected by naturally occurring arsenic. All sampled private wells in Outagamie and Winnebago Counties which exceed the health advisory for arsenic are within a $8.0 \mathrm{~km}(5$ mile) area surrounding the mapped St. Peter Sandstone subcrop. This subcrop refers to the area where the St. Peter Sandstone is nearest to the surface. Greater than 75 percent of the private wells exceeding the health advisory are within $3.2 \mathrm{~km}$ ( 2 miles) of the subcrop. The distribution of wells within various arsenic concentration ranges were used to develop an arsenic advisory area in Outagamie and Winnebago Counties. Since most private wells within Outagamie and Winnebago Counties range between $30.5 \mathrm{~m}$ and $48.8 \mathrm{~m}$ (100 and $160 \mathrm{ft}$ ) deep, wells within the advisory area commonly draw water from the St. Peter Sandstone. Those private wells, located outside the $8.0 \mathrm{~km}$ (5 mile) boundary from the St: Peter Sandstone, that are drilled deeper than normal may encounter the formation and therefore may contain arsenic as has happened in Brown County ten miles downdip eastward.

This study has provided evidence that the arsenic found in the groundwater in Outagamie, Winnebago and Brown Counties is of natural origin. First, the pattern of contaminated wells is relatively widespread covering an area of approximately $951 \mathrm{~km}^{2}(367$ 


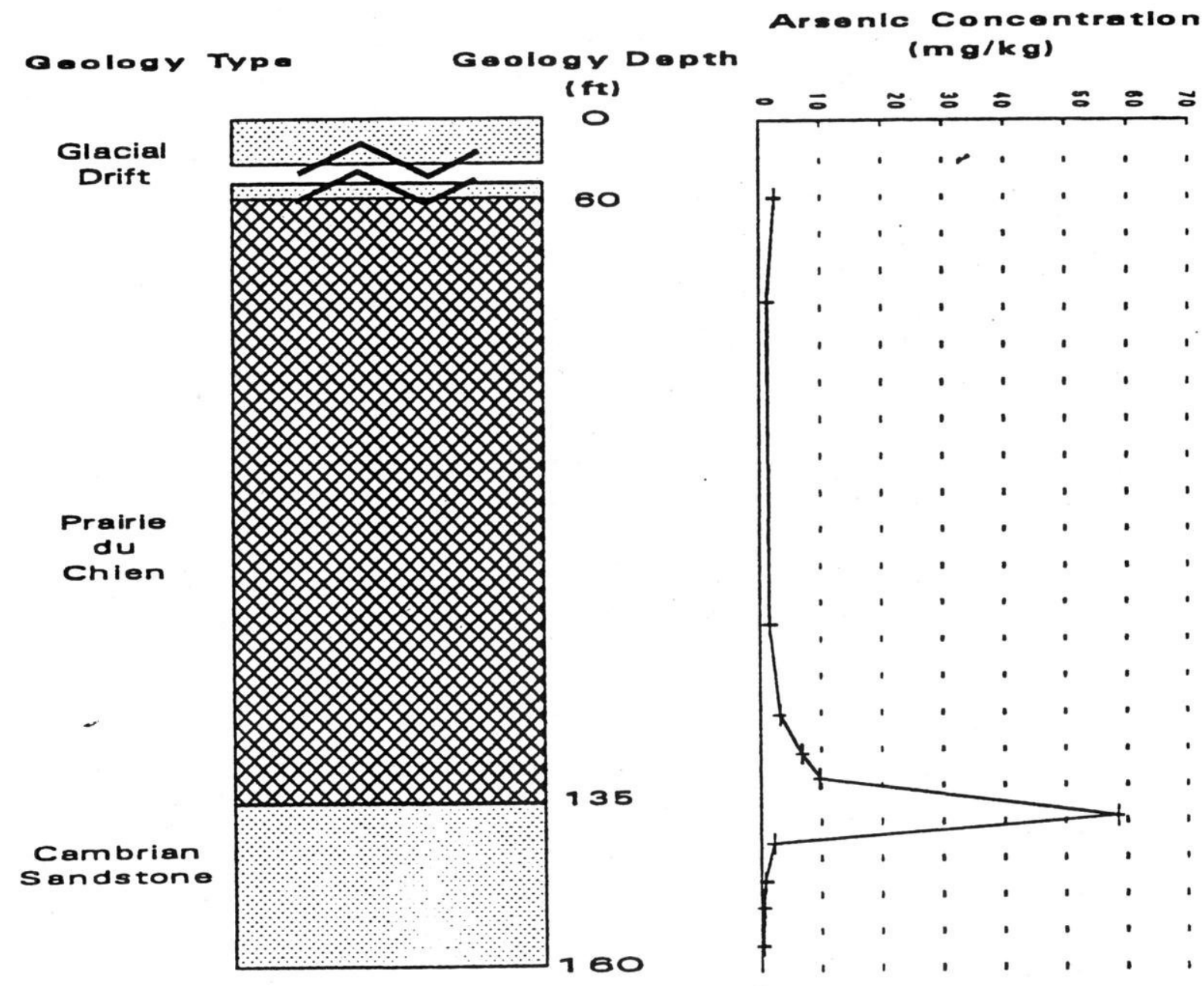

Figure 10 . Drill Cutting Results for Well Number 4. 


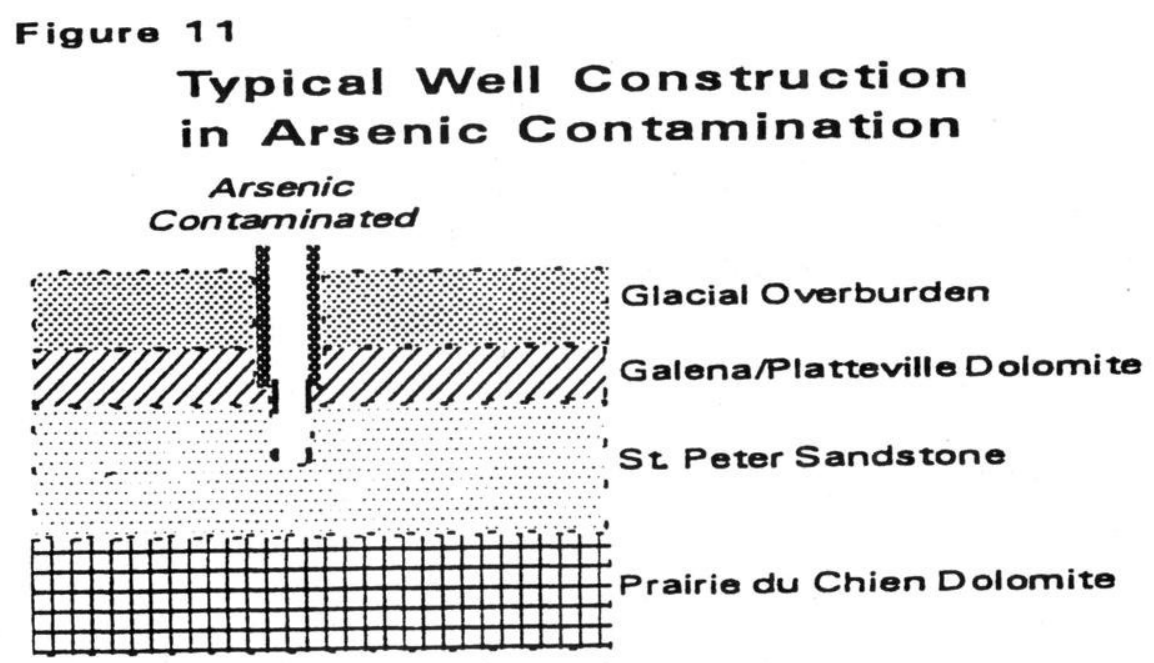

Well Construction Options to Avoid Arsenic Contamination

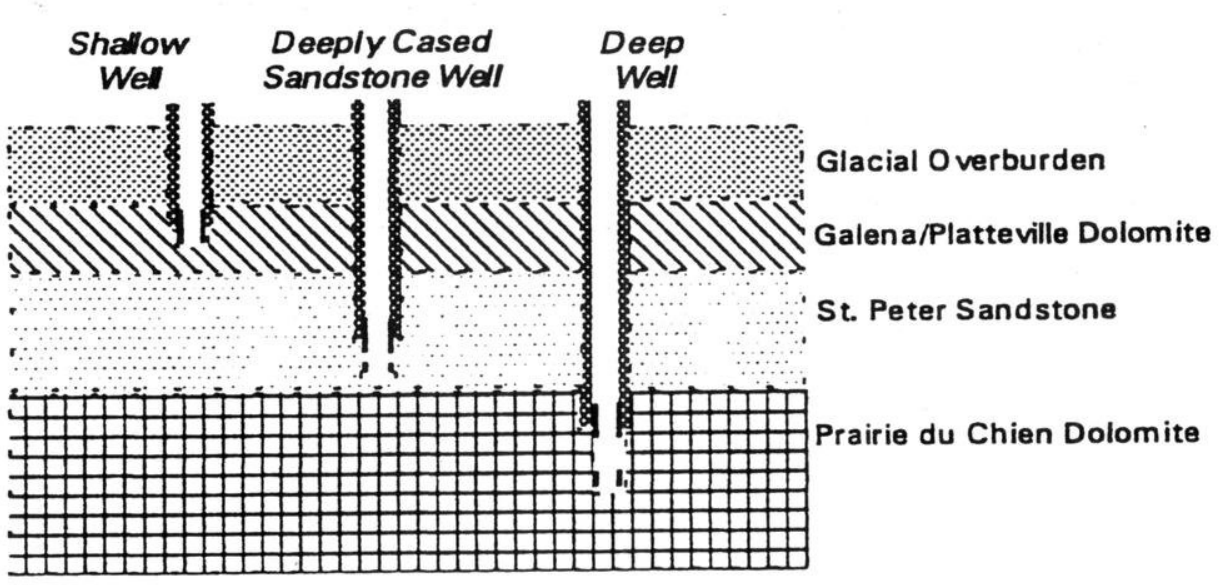


$\mathrm{mi}^{2}$ ). The aerial extent of the contamination alone clearly suggests that the source of arsenic is not of an anthropogenic source. Second, analysis of drill cuttings from various geologic formations, especially in the upper St. Peter Sandstone, have identified specific zones in various geologic strata with high levels of arsenic. Third, well packer tests have shown that groundwater from these zones have the highest levels of arsenic.

There are a number of natural sources that may possibly contribute to arsenic in groundwater. Arsenic with pyrite as its principal carrier in rocks, tends to be associated with mineral deposits of sulfides and sulfo-salts. The presence of pyrite was identified and examined in the Well 6 drill cuttings. Pyrite may exist in layers within the upper St. Peter Sandstone or lower Platteville/Galena Dolomite and thus potentially contribute arsenic to groundwater as evidenced by high iron and sulfate concentrations found with high arsenic concentrations as observed in water samples from Wells 5 and 1.

Recommendations identified through this project for private well users to eliminate or greatly reduce their exposure to arsenic in their drinking water supply are:

(1) purchase bottled water,

(2) install a state approved water treatment device such as a distillation or reverse osmosis unit,

(3) reconstruct an existing well, or

(4) drill a new well to avoid the upper Saint Peters Sandstone formation for water withdrawal.

To avoid high arsenic the St. Peter Sandstone formation should not be penetrated especially near the mapped subcrop. If it is necessary to drill through the St. Peter Sandstone to obtain a sufficient volume of water, the upper portions should be cased off to prevent this part of the formation from supplying water to the well. Private residences whose well water exceeded the health advisory for arsenic are now supplied well water from newly constructed wells based on these recommendations. All of the new wells reduced arsenic concentration in the water by removing the upper St. Peter Sandstone unit as the primary water source.

Based primarily on the results of this study, the WDNR has established guidelines for well drillers constructing wells within the advisory area of $8.0 \mathrm{~km}$ (5 mile) around the St. Peter Sandstone trend in Outagamie and Winnebago Counties. The guidelines serve as an aid to reduce arsenic in water which recharges new wells, and recommend the sampling of new private wells in the area for arsenic.

Health studies on individuals that have unknowingly been exposed to elevated arsenic levels from their water supply is also ongoing. Few studies currently exist on the effects of chronic exposure to arsenic.

Further examination of the conditions which cause naturally low $\mathrm{pH}$ in groundwater is occurring. Three wells in this study had an unusually low $\mathrm{pH}$, which appears to be caused by the presence and oxidation of pyrite. This project identifies the low $\mathrm{pH}$ found in these wells is due to natural sources. 


\section{ACKNOWLEDGMENTS}

We gratefully acknowledge the contribution of others to this work. Dr. James Wiersma, Dr. Ronald Stieglitz, and Dr. David Jowett, acknowledgements of the University of Wisconsin Green Bay for editing and insightful comments on the manuscript. We are deeply indebted to Dr. James Wiersma for the advice and use of his laboratory facilities. Nicole LaPlant, Kristin Nell, Sally Gagnon, Barb Maenpaa, and Annette Weissbach performed field work and compiled data. Mike Hronek created computerized maps with PC Arc Info Geographic Information system software. Funding was furnished by the Wisconsin Department of Natural Resources Groundwater Management Practice Monitoring Program which receives appropriations from the groundwater account. Additional funding for laboratory analytical work was also provided by the University of Wisconsin Green Bay. 


\section{REFERENCES CITED}

Bierens de Haan, Sophie, 1991. A review of the rate of pyrite oxidation in aqueous systems at low temperature. Earth Science Reviews. 31;1-10.

Boyle, R.W., and Jonasson, I.R. 1973. The geochemistry of arsenic and its use as an indicator element in geochemical prospecting. Journal of Geochemical Exploration. 2;251-296.

Burkel, R.S., 1993. Arsenic as a Naturally Elevated Parameter in Water Wells in Winnebago and Outagamie Counties, Wisconsin. M.S. thesis, Department of Environmental Sciences, University of Wisconsin - Green Bay. pp. 111 (unpublished).

Carlson, B.L., Ellis, H.V., and McCannn, J.L. 1986. Toxicology and Biological Monitoring of Metals in Humans. Michigan, Lewis Publishers. pp.27-33.

Dragun, James, 1988. The Soil Chemistry of Hazardous Materials. The Hazardous

Materials Control Research Institute. Silver Spring, Maryland. pp. 77

Driscoll, F.G. 1986. Groundwater and Wells. St. Paul, Minnesota, Johnson Division. pp. 94-96,191-193.

Eisler, R. 1988. Arsenic hazards to fish, wildlife, and invertebrates: a synoptic review. U.S. Fish and Wildlife Service. (Department of Interior)

Elmsley, John. 1985. Whatever happened to arsenic? New Scientist. 19;10-14.

Frank, P., and Clifford, D. 1986. Arsenic (III) oxidation and removal from drinking water. EPA/600/2-86/021.

Irgolic, K.J. 1982. Speciation of arsenic compounds in water supplies. EPA 600/1-82-010.

LeRoux, E.F. 1957. Geology and groundwater resources of Outagamie County, Wisconsin. Geological Survey Water-Supply Paper 1421.

Lindorf, D.E., Feld, J., and Connelly, J. 1987. Groundwater Sampling Procedures Guidelines. Wisconsin Department of Natural Resources Publication. PUBL WR-15387.

Lindorf, D.E., Feld, J., and Connelly, J. 1987. Groundwater Sampling Procedures Field Manual. Wisconsin Department of Natural Resources Publication. PUBL WR-168-87.

Lohr, T. 1985. Wisconsin Department of Natural Resources (WDNR) September 25, Correspondence/Memorandum on County Plumbing Census Data to District Water Supply Supervisors.

Manahan, S.E. 1991. Environmental Chemistry, 5th edition. Michigan, Lewis Publishers. pp. 138-141, 376-377. 
Marquis, J. 1989. A Guide to General Toxicity. Switzerland, Karger. pp.238-240.

Meyer, E. 1989. Chemistry of Hazardous Materials. New Jersey, Prentice-Hall Inc. pp.307.

Olcott, P.G. 1966. Geology and water resources of Winnebago County, Wisconsin. Geological Survey Water-Supply Paper 1814.

Rider, M.H. 1986. The Geological Interpretation of Well Logs. John Wiley and Sons. New York.pp. 57-76.

Smith, A.H., Hopenhayn-Rich, C., Bates, M.N., Goeden, H.M., Hertz-Picciotto, I., Duggan, H.M., Wood, R., Kosnett, M.J., and Smith, M.T. 1992. Cancer Risks from Arsenic in Drinking Water. Environmental Health Perspective

Smith, S.A. and Tuovinen, O.H. 1985. Environmental analysis of iron-precipitating bacteria in groundwater and wells. Ground Water Monitoring Review. pp.45-52.

Thwaites, F.T. 1961. The base of the St. Peter Sandstone in southwestern Wisconsin. Wisconsin Academy of Sciences, Arts, and Letters. 50:203-19.

U.S. Environmental Protection Agency (EPA). 1982. Preliminary study of sources of inorganic arsenic. EPA-450/5-82-005.

U.S. Environmental Protection Agency (EPA). 1990. Drinking water from household wells. EPA-570/9-90-013.

Wisconsin Department of Health and Social Services (WDHSS). 1990. Toxic Chemical Series, Arsenic.

Wisconsin Geological and Natural History Survey (WGNHS). 1991. Pamphlet on The Importance of Accurate Well Constructor's Reports from January. 